\title{
Preparation and Powder XRD Analysis of Tris(2,2'-bipyridine)nickel(II) Trifluoroacetate
}

\author{
Kristian Handoyo Sugiyarto*, Isana Supiah Yosephine Louise, and Shinta Setya Wilujeng \\ Department of Chemistry Education, Universitas Negeri Yogyakarta, Jl. Colombo No. 1, Yogyakarta 55281, Indonesia
}

\section{*Corresponding author:}

email:sugiyarto@uny.ac.id

Received: June 9, 2019

Accepted: August 7, 2019

DOI: $10.22146 /$ ijc.46483

\begin{abstract}
The complex containing Ni(II)-2,2'-bipyridin (bipy)-trifluoroacetate (TFA) was prepared by direct interaction of the corresponding precursors in an aqueous solution. AAS measurement for metal content, TGA-DTA analysis and electrical conductance suggest the ionic complex of $\left.[\mathrm{Ni} \text { (bipy) })_{3}\right]\left(\mathrm{CF}_{3} \mathrm{COO}\right)_{2} \cdot 6 \mathrm{H}_{2} \mathrm{O}$. The magnetic moment of 3.13-3.17 BM indicates the paramagnetism corresponding to two unpaired electrons which is clearly higher than that of the spin only value (2.87 BM), and commonly observed due to the spin-orbit coupling in Ni(II). UV-Vis spectral property revealed the first two main ligand field bands centered at about 14200 and $18650 \mathrm{~cm}^{-1}$, which are attributed to the spin-allowed transition, ${ }^{3} A_{2 g} \rightarrow{ }^{3} T_{2 g}$ and ${ }^{3} A_{2 g} \rightarrow{ }^{3} T_{1 g}(F)$, respectively. The expected third band at higher energy seems to appear as a shoulder at $26500 \mathrm{~cm}^{-1}(378 \mathrm{~nm})$, as it is masked by a strong intensity of charge transfer band centered at $31050 \mathrm{~cm}^{-1}$. The infrared spectrum exhibits mode of vibrations of the functional groups of ligand and TFA. The powder diffractogram was refined by Le Bail method and found fit as monoclinic system of space group of $P 2_{1} / M$, with figures of merit: $R_{p}=3.62, R_{w p}=5.76, R_{\text {exp }}=3.48$, goodness of fitting (GOF) 2.745 and the derived Bragg $R$-Factor $=0.05$.
\end{abstract}

Keywords: Rietica; Le Bail; bipy; trifluoroacetate; nickel(II)

\section{- INTRODUCTION}

The chemistry of 2,2'-bipyridine (bipy) as a bidentate ligand has been well known for tris-bipy complex since long time ago [1]. However, the crystallographic aspects of the corresponding single crystals are scarcely reported. It is not surprising since the preparation of a single crystal suitable for refining the structural data of particular complex is sometimes quite complicated and even unsuccessful. Rietica is one of known programs of Le Bail to refine the lattice parameters for various metal oxides [2-4] which are found to be fit, and it seems also applicable for other powders of complexes. The first complex refined by Le Bail program was initially reported in 1999 [5] for octahedral $\left[\mathrm{Co}\left(\mathrm{NH}_{3}\right)_{5} \mathrm{CO}_{3}\right]\left(\mathrm{NO}_{3}\right) \cdot \mathrm{H}_{2} \mathrm{O}$ complex which was found very good result with the figures of merit to be $R_{B}=0.053$, $R_{p}=0.100, R_{w p}=0.119$. Although the application to other complexes were not continually reported since then it has been applied to some complexes as reported quite recently by Sugiyarto et al. [6], Kusumawardani et al. [7-8] and Sutrisno et al. [9]. Therefore, refining diffractogram of powder complexes seems to be an alternative way to identify the corresponding lattice parameters. Trifluoroacetate (TFA) of alkali metals have been known to be ionic salts because the corresponding acid, HTFA, is known as a strong acid ( $p \mathrm{Ka}=0.23)$, being about 100,000 times stronger than that of acetic acid $(p \mathrm{Ka}=$ 4.76) [10-11]. The highly electronegative fluorine atoms in trifluoromethyl group should weaken the oxygenhydrogen bond and stabilizes the anionic conjugate base. However, the coordination nature of oxygen atom in acetate group is possible, and with transition metal ions some polynuclear molecular complexes of TFA have been synthesized [12]. The monodentate coordinating with hydrogen bonding of $\mathrm{N}-\mathrm{H} \cdots \mathrm{O}$ has also been observed [13]. Some molecular complexes containing monodentate pyridine with TFA, $\left[\mathrm{M}(p y)\left(\mathrm{CF}_{3} \mathrm{CO}_{2}\right)\right]$, where $\mathrm{M}=\mathrm{Cu}(\mathrm{II}), \mathrm{Ni}(\mathrm{II})$, and $\mathrm{Co}(\mathrm{II})$, have also been characterized [14]. TFA has been considered as weakly coordinating ligand in $[\mathrm{Ni}(o-$ $\mathrm{MeO}$-dppp)(TFA $\left.)_{2}\right]$, where dppp $=1,3$-bis[di $(o-$ methoxyphenyl)phosphanyl]propane, as reported to 
undergo completely auto-ionized in polar solvents [15], indicating that TFA was no longer to be a ligand in the solution but a counter anion. Therefore, in the presence of relatively strong ligand such as bipyridine (bipy), the role of TFA might be considered as a counter anion, and the preparation of $\mathrm{Ni}(\mathrm{II})$ with bipy and TFA should be significantly evident as in this work. Moreover, to the corresponding powder of the complex its cell parameters might be then revealed by Rietica-Le Bail method, and these are the main purpose of this work.

\section{- EXPERIMENTAL SECTION}

\section{Materials}

The main reagents, nickel(II) nitrate $\left(\mathrm{Ni}\left(\mathrm{NO}_{3}\right)_{2} \cdot 6 \mathrm{H}_{2} \mathrm{O}\right), 2$,2'-bipyridine $\left(\mathrm{C}_{10} \mathrm{H}_{8} \mathrm{~N}_{2}\right)$, sodium trifluoroacetate $\left(\mathrm{CF}_{3} \mathrm{COONa}\right)$, ammonium nitrate $\left(\mathrm{NH}_{4} \mathrm{NO}_{3}\right)$, calcium chloride $\left(\mathrm{CaCl}_{2}\right)$, nickel sulfate $\left(\mathrm{NiSO}_{4}\right)$, calcium nitrate $\left(\mathrm{Ca}\left(\mathrm{NO}_{3}\right)_{2}\right)$, and aluminium nitrate $\left(\mathrm{Al}\left(\mathrm{NO}_{3}\right)_{3} \cdot 6 \mathrm{H}_{2} \mathrm{O}\right)$, Iron(III) chloride $\left(\mathrm{FeCl}_{3}\right)$ were obtained from Aldrich-Sigma, and directly used without special treatment.

\section{Procedure}

\section{Procedure for preparation of the complex}

The mixture of $0.1 \mathrm{mmol}$ nickel nitrate and $0.32 \mathrm{mmol}$ bipyridine in about $15 \mathrm{~mL}$ aqueous solution with drops of ethanol in a $50 \mathrm{~mL}$ flask was well stirred and warmed till solution become clear. Saturated aqueous solution of $\mathrm{CF}_{3} \mathrm{COONa}$ in excess $(0.4 \mathrm{mmol}, 5 \mathrm{~mL})$ was then poured to this mixture. The volume was reduced on warming, whereupon the light-pink solid was deposited on cooling while scratching. The precipitate was filtered off, washed with a minimum cold water, and finally dried in exposure.

\section{Instruments and procedure of physical measurements}

Magnetism. Magnetic Susceptibility Balance (MSB) of Auto Sherwood Scientific 240V-AC was used to measure the magnetic susceptibility in mass $\left(\chi_{\mathrm{g}}\right)$ of samples. This instrument was calibrated with $\mathrm{CuSO}_{4} \cdot 5 \mathrm{H}_{2} \mathrm{O}$ before running the samples. The powder complex was tightly packed in the Gouy tube till the sign of volume. The difference in mass without and with (electro-)magnet which reflects the magnetic susceptibility in mass was then recorded. It was converted into molar magnetic susceptibility $\left(\chi_{\mathrm{M}}\right)$ and then corrected for diamagnetism using Pascal's constant [16] to get corrected molar magnetic susceptibility $\left(\chi_{M}^{\prime}\right)$. The effective magnetic moment $\left(\mu_{\text {eff }}\right)$ was then calculated from the general formula, $\mu_{\text {eff }}=2.828 \sqrt{ }\left(\chi_{M}^{\prime} \cdot T\right)$ BM.

UV-Vis electronic and infrared spectra. A spectrophotometer model of Pharmaspec UV 1700 was used to record the UV-VIS electronic spectrum. The sample was spread and pasted with ethanol on a particular thin glass $(2 \times 2 \mathrm{~cm})$. The fitting was then set in the cell holder and the spectrum was recorded at 300$800 \mathrm{~nm}$. An Infrared Spectrophotometer of FTIR ABB MB3000 model was used to record the IR-spectrum of sample. The sample which was mixed with $\mathrm{KBr}$ was pressed on the cell and then the spectrum was recorded at $600-4000 \mathrm{~cm}^{-1}$.

Metal content and ionic property. An Atomic Absorption Spectrophotometer of PinAAcle 900T Perkin Elmer model was used to record the metal content. A conductometer of Lutron CD-4301 model was used to estimate the conductance property of the complex. It was calibrated with an aqueous solution of 1 $\mathrm{M} \mathrm{KCl}$ at $25{ }^{\circ} \mathrm{C}$, and some known ionic solutions, $\mathrm{NH}_{4} \mathrm{NO}_{3}, \mathrm{CaCl}_{2}, \mathrm{Ca}\left(\mathrm{NO}_{3}\right)_{2}, \mathrm{NiSO}_{4}, \mathrm{MnSO}_{4}, \mathrm{FeCl}_{3}$, and $\mathrm{Al}\left(\mathrm{NO}_{3}\right)_{3}$, were also recorded for comparison.

TGA-DTA (Thermogravimetric analysis and differential thermal analysis). The loss of hydrated molecule of water and decomposition of complex was performed on Diamond (Perkin Elmer Instruments), and simultaneous TGA-DTA were obtained by a NETZSCH STA 409C/CO thermal analyzer model with the rate of $10^{\circ} \mathrm{C} / \mathrm{min}$.

Powder diffraction. A Rigaku Miniflex $60040 \mathrm{~kW}$ $15 \mathrm{~mA}$ Benchtop Diffractometer with $\mathrm{Cu} K_{\alpha}, \lambda=1.5406 \AA$ was used to record the diffractogram of the complex. The sample was spread on a special glass plate and set on the cell holder. The diffractogram was then recorded in a scan mode at 2-90 degree of $2 \theta$ within interval of 0.04 steps per $4 \mathrm{sec}$ for $2 \mathrm{~h}$. The recorded diffractogram was then refined following the Le Bail method of Rietica program within 10-50 degree of $2 \theta$ which was run within 75 cycles. 
SEM-EDX (Scanning electron microscopy with energy dispersive X-ray). The SEM images of the complex were recorded in JEOL JED-2300 model to confirm the crystallinity as well as the content of main elements in the sample.

\section{- RESULTS AND DISCUSSION}

\section{Conductance, TGA-DTA and Formula of the Complex}

The mixture of light-green nickel(II) and colorless bipyridine which produced light-pink color was likely to be the cationic complex, $\left[\mathrm{Ni}\left(b_{i p y}\right)_{n}\right]^{2+}$. The addition of anionic TFA in excess should force the precipitated complex containing TFA. The conductivity data of the complex and several known ionic compounds in aqueous solution are listed in Table 1. It indicates strongly that the conductance for this complex is clearly in the range for those compounds containing three ions per molecule, and hence the best possible empirical formula, $\left[\mathrm{Ni}(\text { bipy })_{n}\right]\left(\mathrm{CF}_{3} \mathrm{COO}\right)_{2} \cdot x \mathrm{H}_{2} \mathrm{O}$, might be proposed for the pink powdered complex.

Estimation of coordination number $(n)$ in the formula of the complex could be worked out by considering the metal content obtained from AAS (calculated $6.81 \%$ and found $6.77 \%$ ), which was then confirmed further by the loss of mass for each of other components indicated in TGA-DTA graph as shown in Fig. 1 and Table 2. In this graph, the first stage of mass loss for about $11.87 \%$ at around $100^{\circ} \mathrm{C}$ is almost certainly due to the loss of uncoordinated water molecules [9,17-19]. This corresponds to $5.68 \mathrm{H}_{2} \mathrm{O}$ which is close to the calculated percentage of $12.53 \%$ for $6 \mathrm{H}_{2} \mathrm{O}$. The next two stages of mass loss in the range of $120-260{ }^{\circ} \mathrm{C}$, could be put together to a total of about $25.71 \%$ for decomposition

Table 1. Electrical equivalent conductance of the complex and some known salts in aqueous solutions

\begin{tabular}{lccc}
\hline Compounds & $\begin{array}{c}\text { Equivalent conductance } \\
(\Lambda \mathrm{c}) \Omega^{-1} \mathrm{~cm}^{2} \mathrm{~mol}^{-1}\end{array}$ & $\begin{array}{c}\text { Amount ratio of } \\
\text { cation/anion }\end{array}$ & $\begin{array}{c}\text { Number of ions } \\
\text { per molecule }\end{array}$ \\
\hline $\mathrm{NH}_{4} \mathrm{NO}_{3}$ & 128.176 & $1: 1$ & 2 \\
$\mathrm{NiSO}_{4}$ & 119.55 & $1: 1$ & 2 \\
$\mathrm{CaCl}_{2}$ & 196.90 & $1: 2$ & 3 \\
$\mathrm{Ca}\left(\mathrm{NO}_{3}\right)_{2}$ & 229.340 & $1: 2$ & 3 \\
$\mathrm{Al}\left(\mathrm{NO}_{3}\right)_{3}$ & 510.010 & $1: 3$ & 4 \\
$\mathrm{FeCl}$ & 573.820 & $1: 3$ & 4 \\
{$\left[\mathrm{Ni}(\text { bipy })_{n}\right]\left(\mathrm{CF}_{3} \mathrm{COO}\right)_{2} \cdot x \mathrm{H}_{2} \mathrm{O}$} & $\mathbf{2 1 4 . 5 9 8}$ & $\mathbf{1 : 2}$ & $\mathbf{3}$ \\
\hline
\end{tabular}

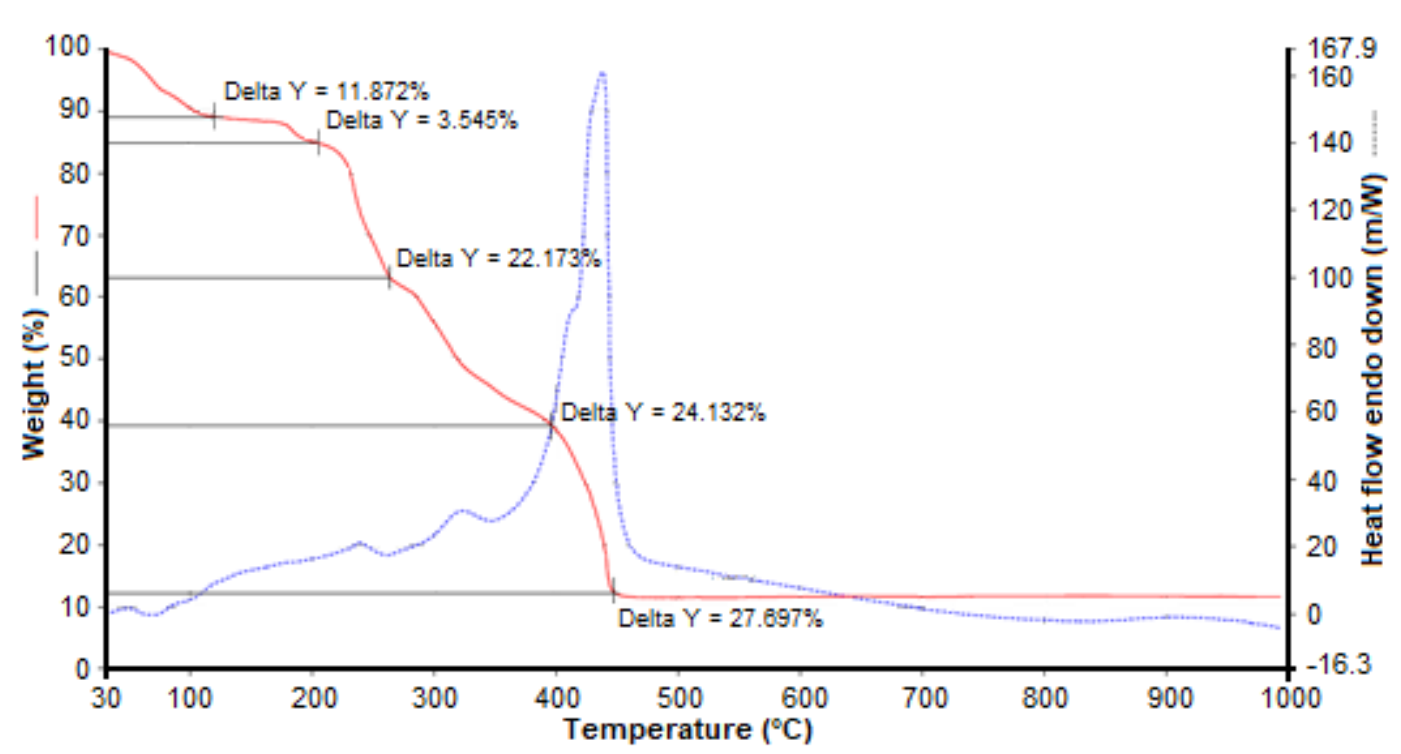

Fig 1. The TGA-DTA of $\left[\mathrm{Ni}(\text { bipy })_{3}\right]\left(\mathrm{CF}_{3} \mathrm{COO}\right)_{2} \cdot 6 \mathrm{H}_{2} \mathrm{O}$ at $30-1000{ }^{\circ} \mathrm{C}$ 
Table 2. Entity found in $\left[\mathrm{Ni}(\text { bipy })_{3}\right]\left(\mathrm{CF}_{3} \mathrm{COO}\right)_{2} \cdot 6 \mathrm{H}_{2} \mathrm{O}$

\begin{tabular}{lccccc}
\hline Type & $\mathrm{Ni}$ & $\mathrm{H}_{2} \mathrm{O}$ & $\left(\mathrm{CF}_{3} \mathrm{COO}\right)$ & (bipy) & $\mathrm{NiO}_{2}{ }^{*}$ \\
\hline Found & 6.77 & 11.87 & 25.71 & 51.83 & 10.58 \\
Calculated & 6.81 & 12.53 & 26.24 & 54.39 & 10.53 \\
Error (\%) & 0.58 & 5.26 & 2.13 & 4.72 & 0.47 \\
Method & AAS & TGA & TGA & TGA & TGA \\
\hline
\end{tabular}

${ }^{*} \mathrm{NiO}$ (cal. 8.67\%) as the residue observed on the graph above $700{ }^{\circ} \mathrm{C}$

of TFA as also observed by Eloussifi et al. [20]. This percentage loss equals 1.96 moles of TFA anions, which is reasonably close to the calculated loss of $26.24 \%$ for 2 moles in this complex. The next loss of mass observed in the range $400-450{ }^{\circ} \mathrm{C}$ for about $51.83 \%$ should be associated with loss of 2.86 moles of bipyridine, though the calculated for 3 moles is $54.39 \%$ in this instance. Laishram [21] proposed the loss of bipyridine at 285$476{ }^{\circ} \mathrm{C}$. As Singh et al. suggested [22] the remaining loss observed to be $10.58 \%$ approximately refers to $\mathrm{NiO}_{2}$ which is calculated as $10.53 \%$ in mass, before further decomposition to the residue $\mathrm{NiO}$ (cal. 8.67\%) as indicated by the graph below $700{ }^{\circ} \mathrm{C}$. For those reasons, it can be concluded that the proposed formula, $\left[\mathrm{Ni}(\text { bipy })_{3}\right]\left(\mathrm{CF}_{3} \mathrm{COO}\right)_{2} \cdot 6 \mathrm{H}_{2} \mathrm{O}$, for the complex would be reasonably fit as being expected also from the stoichiometric preparation. The electrolyte nature in aqueous solution for this complex as reflected by conductivity data confirms strongly the ionic property of the TFA rather than the coordinated one [14], and thus, the next particular characterization is described.

\section{Magnetic Property}

Based on the complex formula (Table 2), the magnetic susceptibility recorded on the measurements (Table 3) were then worked out to the magnetic moments and for the three separated samples they are in the range 3.13-3.17 BM. It is certainly higher than the spin-only value for the two unpaired electrons $(2.83 \mathrm{BM})$ in the electronic configuration of $d^{8}-\mathrm{Ni}(\mathrm{II})$, which is commonly observed due to the orbital contribution by 'mixing in' of the wave-functions of the higher ${ }^{3} \mathrm{~T}$ terms [23-24].

\section{Electronic Spectrum}

Electronic spectrum of the powdered complex, $\left[\mathrm{Ni}(\text { bipy })_{3}\right]\left(\mathrm{CF}_{3} \mathrm{COO}\right)_{2} \cdot 6 \mathrm{H}_{2} \mathrm{O}$, was recorded in the range
300-800 nm. As displayed in Fig. 2 the two main ligand field bands were well resolved, and centered at about $13700 \mathrm{~cm}^{-1}(730 \mathrm{~nm})\left(\mathrm{v}_{1}\right)$ and $18650 \mathrm{~cm}^{-1}(536 \mathrm{~nm}),\left(\mathrm{v}_{2}\right)$; these are associated with the spin-allowed transitions, ${ }^{3} \mathrm{~A}_{2 \mathrm{~g}} \rightarrow{ }^{3} \mathrm{~T}_{2 \mathrm{~g}}$, and ${ }^{3} \mathrm{~A}_{2 \mathrm{~g}} \rightarrow{ }^{3} \mathrm{~T}_{1 \mathrm{~g}}(\mathrm{~F})$, respectively. This spectrum is quite similar to that of the tetrafluoroborate recorded by Abramov [25], and the second band being responsible for the pink color. The expected third band, $\mathrm{V}_{3}\left({ }^{3} \mathrm{~A}_{2 \mathrm{~g}}(\mathrm{~F}) \rightarrow{ }^{3} \mathrm{~T}_{1 \mathrm{~g}}(\mathrm{P})\right)$, as predicted by Tanabe-Sugano to be at higher energy about $26500 \mathrm{~cm}^{-1}(278 \mathrm{~nm})$ was not well resolved but as a shoulder due to the masked strong intensity of charge transfer (MLCT) band of $31050 \mathrm{~cm}^{-1}$ $(322 \mathrm{~nm})$.

\section{Infrared Spectrum}

Infrared spectra of the complex and the TFA-salt were recorded and overlaid as shown in Fig. 3, and thus the assignment seems straight forward. The broad band (Fig. 3(a)-red full line) at about $3400 \mathrm{~cm}^{-1}$ is likely to be -OH stretching of $\mathrm{H}_{2} \mathrm{O}$ molecules in the complex as confirmed by TGA-DTA (Fig. 1). Shad et al. observed this

Table 3. Magnetic data of $\left[\mathrm{Ni}(b i p y)_{3}\right]\left(\mathrm{CF}_{3} \mathrm{COO}\right)_{2} \cdot 6 \mathrm{H}_{2} \mathrm{O}$ at $291{ }^{\circ} \mathrm{C}$

\begin{tabular}{ccc}
\hline Sample & $\chi_{\mathrm{M}}{ }^{\prime} \times 10^{-6}(\mathrm{cgs})$ & $\mu_{\text {eff. }}(\mathrm{BM})$ \\
\hline 1 & 4.4326 & 3.15 \\
2 & 4.3734 & 3.13 \\
3 & 4.5128 & 3.17 \\
\hline
\end{tabular}

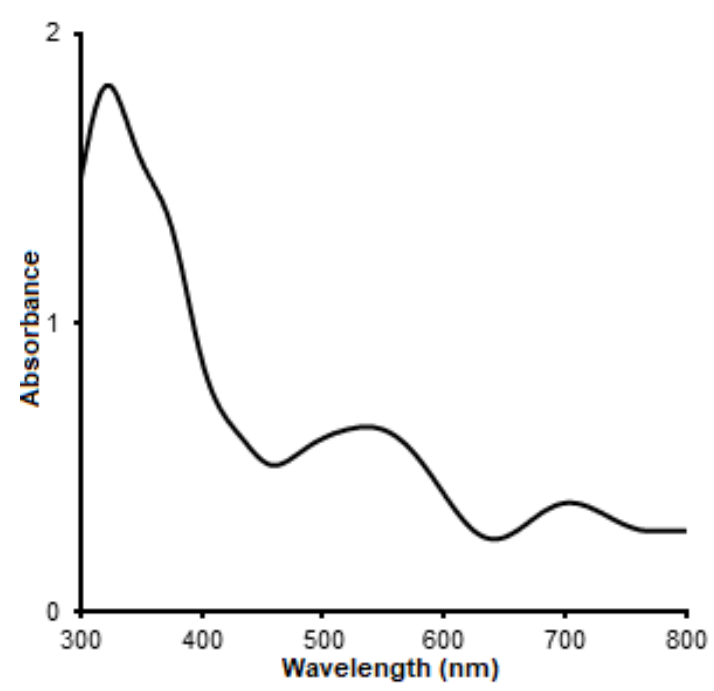

Fig 2. Electronic spectrum of powder $\left[\mathrm{Ni}(\text { bipy })_{3}\right]\left(\mathrm{CF}_{3} \mathrm{COO}\right)_{2} \cdot 6 \mathrm{H}_{2} \mathrm{O}$ 


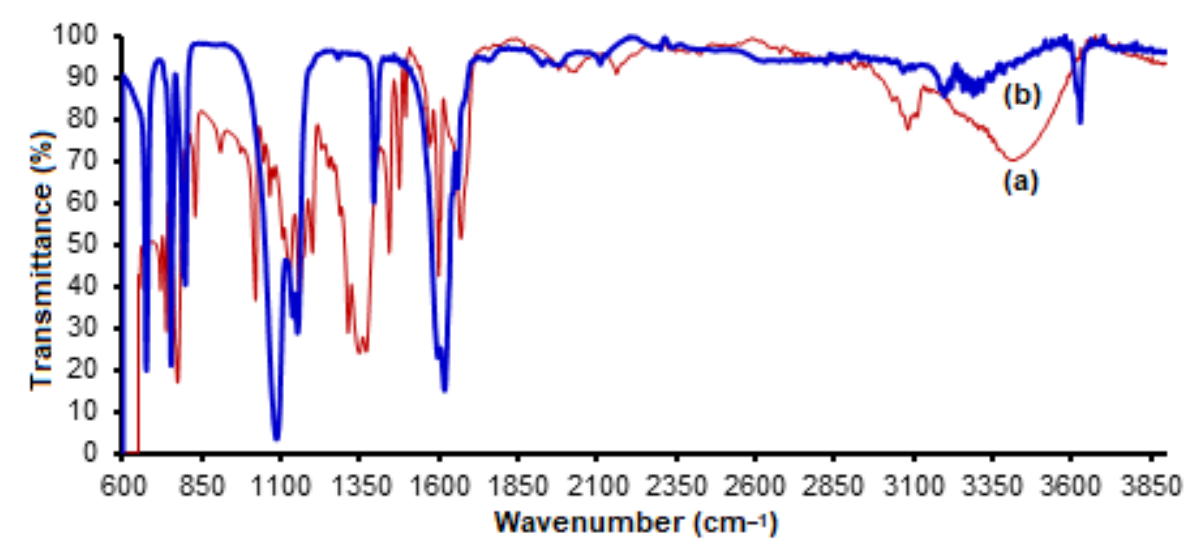

Fig 3. Infrared spectrum of $\left[\mathrm{Ni}(\text { bipy })_{3}\right]\left(\mathrm{CF}_{3} \mathrm{COO}\right)_{2} \cdot 6 \mathrm{H}_{2} \mathrm{O}$ (red, (a)) and $\mathrm{Na} \mathrm{CF}_{3} \mathrm{COO}$ (blue, (b))

assignment at about $3441 \mathrm{~cm}^{-1}$ [26], though Kumar et al. [27] also considered C-C aromatic at $3430 \mathrm{~cm}^{-1}$. Another band at $3100 \mathrm{~cm}^{-1}$ might be assigned as stretching vibration of C-H bonds as observed by Chen et al. at $3064 \mathrm{~cm}^{-1}$ in phenanthroline [28], and Tosonian et al. at $3051-3068 \mathrm{~cm}^{-1}$ [29]. As reported previously, typical vibrations of bipy might be shifted due to chelation [1]. Characteristic vibration of bipyridine ( $v_{\mathrm{C}-\mathrm{C}}$ and $v_{\mathrm{C}-\mathrm{N}}$ ) are in the range 1650 $1400 \mathrm{~cm}^{-1}[28,30]$, and in this instance, they are at 1669 , $1598,1498,1494$, and $1350 \mathrm{~cm}^{-1}$. Zang et al. [31] suggested that the mode of vibration at $1585 \mathrm{~cm}^{-1}$ was to be $v_{\mathrm{C}-\mathrm{N}}$.

The very strong-sharp peaks at about 1660 and $1160 \mathrm{~cm}^{-1}$ are assigned as due to mode of vibrations $v_{(\mathrm{C}=0)}$ and $v_{(\mathrm{C}-\mathrm{O})}$, respectively as observed by Skyranou et al. [32] and Suzuki et al. [33] at $1669 \mathrm{~cm}^{-1}$, and by Osowole et al. [34] at 1192-1102 $\mathrm{cm}^{-1}$. While mode at about $1442 \mathrm{~cm}^{-1}$ might be due to $v_{(\mathrm{C}-\mathrm{C})}$ as proposed by Abdelhak et al. [30]. A very strong mode at $1670 \mathrm{~cm}^{-1}$ might be due to $\mathrm{C}=\mathrm{O}$ stretching vibration as compared to that of sodium TFA (Fig. 3(b)-blue line) which was observed at $1669 \mathrm{~cm}^{-1}$ [32]. The bands at about 750 and $848 \mathrm{~cm}^{-1}$ are deformation asymmetry and symmetry of $\mathrm{CF}_{3}$, respectively [7,35-37], as also observed in sodium TFA at 800 and $850 \mathrm{~cm}^{-1}$. The asymmetric CF deformations normally fall in the 500$625 \mathrm{~cm}^{-1}$ region, and $\mathrm{O}=\mathrm{C}-\mathrm{O}$ bending vibration at $700 \mathrm{~cm}^{-1}[40]$.

\section{The Powder X-Ray Diffractogram and Its Refinement}

Structural data obtained from cationic single crystal of $\left[\mathrm{Ni}(\text { bipy })_{3}\right]^{2+}$ with various counter anions have been established [39-43]. Except for the tetrachloridozincate salt [43], all adopt the same symmetry, monoclinic, but different in space group, and consequently different cell parameters as described in Table 4. Therefore, structural analysis of powder cation $\left[\mathrm{Ni}(\text { bipy })_{3}\right]^{2+}$ with other counter anion, TFA, should be of interest for this aspect.

The powder X-Ray diffractogram of the complex, $\left[\mathrm{Ni}(\text { bipy })_{3}\right]\left(\mathrm{CF}_{3} \mathrm{COO}\right)_{2} \cdot 6 \mathrm{H}_{2} \mathrm{O}$, together with its refining according to Le Bail method is displayed in Fig. 4. The observed data (+ signs, (a)) are almost coincident to the full line of refinement model (b), and it is confirmed by the almost flat curve (c) reflecting difference between the two. This suggests that the analysis is considered to be fit with low figures of merit: $3.62\left(R_{p}\right), 5.76\left(R_{w p}\right), 3.48\left(R_{e x p}\right)$, 2.745 (GOF), and 0.05 (Bragg R-Factor) as discussed by Toby [44] and found in several of so many reported metal oxides [2-4] and several complexes [5-9]. The detailed lattice parameters of this complex are described in Table 4 along with the corresponding cationic single crystal data of different counter anions, the hexamolybdate [39], the perchlorate [40], the bis(2thiobarbiturate)-Htba [41], the chloride [42], and the tetrachloridozincate [43]. It is clear that the cell parameters are quite similar to that of hexamolybdate with all parameters are slightly reduced. With the same number of molecules per cell $(Z=4)$ it is readily understood since the size of counter anionhexamolybdate is greater than that of TFA.

\section{SEM-EDX}

Crystallinity of this powder $\left[\mathrm{Ni}(\text { bipy })_{3}\right]\left(\mathrm{CF}_{3}\right.$ $\mathrm{COO})_{2} \cdot 6 \mathrm{H}_{2} \mathrm{O}$ might be reflected by the corresponding 
Table 4. Detailed cell parameters of $\left[\mathrm{Ni}(\text { bipy })_{3}\right](\mathrm{X})$, where $\mathrm{X}=(\mathrm{TFA})_{2} \cdot 6 \mathrm{H}_{2} \mathrm{O}^{*},\left(\mathrm{Mo}_{6} \mathrm{O}_{19}\right)_{2}[39],\left(\mathrm{ClO}_{4}\right)_{2}[40]$, $(\mathrm{Htba})_{2} \cdot 6 \mathrm{H}_{2} \mathrm{O}$ [41], and $\mathrm{Cl}_{2} \cdot 5.5 \mathrm{H}_{2} \mathrm{O}$ [42], and $\left[\mathrm{ZnCl}_{4}\right]_{2}$ [43] ( ${ }^{\star}$ This work was due to Le Bail method of Rietica program)

\begin{tabular}{|c|c|c|c|c|c|c|}
\hline$\left[\mathrm{Ni}(\text { bipy })_{3}\right](\mathrm{X})$ & $\begin{array}{l}(\mathrm{TFA})_{2} \cdot 6 \mathrm{H}_{2} \mathrm{O} \\
{ }^{*} \text { This work }\end{array}$ & $\begin{array}{c}\left(\mathrm{Mo}_{6} \mathrm{O}_{19}\right)_{2} \\
{[39]}\end{array}$ & $\begin{array}{c}\left(\mathrm{ClO}_{4}\right)_{2} \\
{[40]}\end{array}$ & $\begin{array}{c}(\mathrm{Htba})_{2} \cdot 6 \mathrm{H}_{2} \mathrm{O} \\
{[41]}\end{array}$ & $\begin{array}{c}\mathrm{Cl}_{2} \cdot 5.5 \mathrm{H}_{2} \mathrm{O} \\
{[42]}\end{array}$ & $\begin{array}{c}{\left[\mathrm{ZnCl}_{4}\right]_{2}} \\
{[43]}\end{array}$ \\
\hline Symmetry & Monoclinic & Monoclinic & Monoclinic & Monoclinic & Monoclinic & Trigonal \\
\hline Space Grup & $\mathrm{P} 2_{1} / \mathrm{m}$ & $\mathrm{P} 2_{1} / \mathrm{n}$ & $\mathrm{C} 2 / \mathrm{c}$ & $\mathrm{P} 21 / \mathrm{c}$ & $\mathrm{C} 2 / \mathrm{c}$ & $\mathrm{R} 3 \mathrm{c}$ \\
\hline $\mathrm{Z}$ & 4 & 4 & 4 & 8 & 4 & 12 \\
\hline $\mathrm{a}(\AA)$ & 11.6628 & 12.3549 & $17.502(2)$ & $13.6618(6)$ & $13.410(2)$ & $13.34 .3(2)$ \\
\hline $\mathrm{b}(\AA)$ & 17.8225 & 18.9866 & $10.777(1)$ & $23.9441(9)$ & $22.509(4)$ & \\
\hline$c(\AA)$ & 16.9786 & 17.1974 & $16.092(2)$ & $25.4335(8)$ & $23.781(4)$ & $58.932(12)$ \\
\hline$\beta\left(^{\circ}\right)$ & 98.8477 & 101.114 & $90.959(2)$ & $93.091(1)$ & 105.390 & \\
\hline$V\left(\AA^{3}\right)$ & 3487.1950 & 3958 & $3034.8(6)$ & $8307.7(5)$ & $6921(2)$ & $9087(3)$ \\
\hline \multicolumn{7}{|l|}{ Figure of merit: } \\
\hline$R_{p}$ & 3.62 & & & & & \\
\hline$R_{w p}$ & 5.76 & & & & & \\
\hline$R_{\exp }$ & 3.48 & & & & & \\
\hline Bragg R-Factor & 0.05 & & & & & \\
\hline GOF & 2.745 & & & & & \\
\hline
\end{tabular}

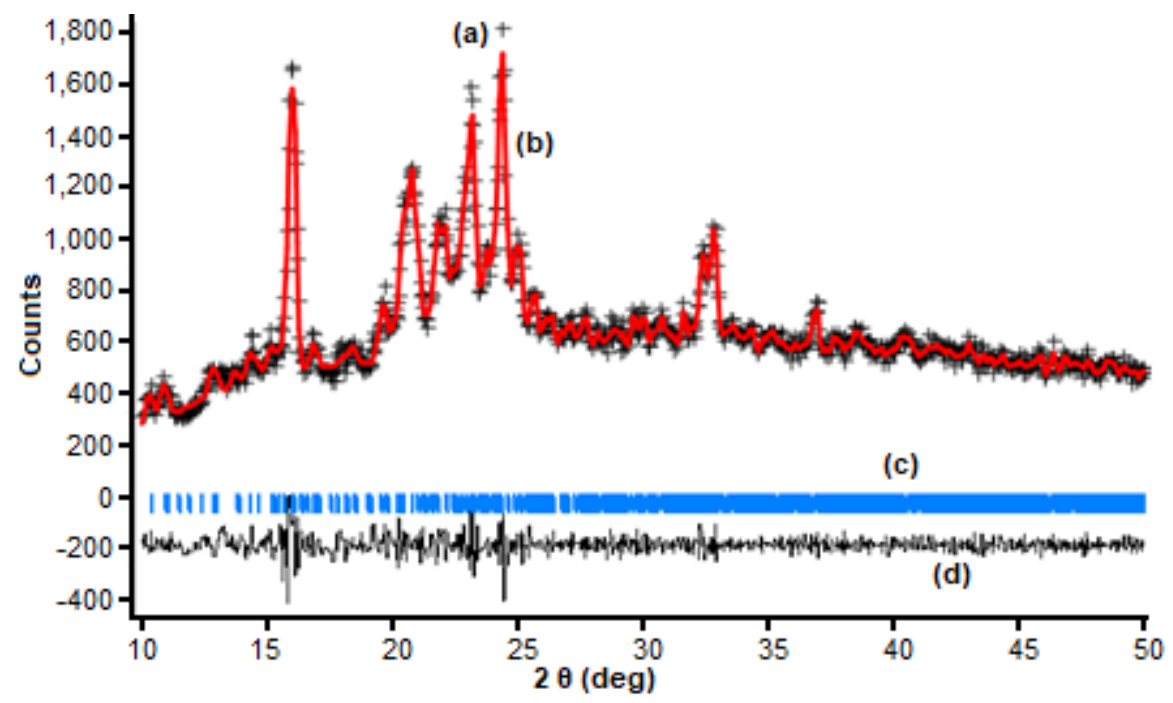

Fig 4. Diffractogram of $\left[\mathrm{Ni}(\text { bipy })_{3}\right]\left(\mathrm{CF}_{3} \mathrm{COO}\right)_{2} \cdot 6 \mathrm{H}_{2} \mathrm{O}$ : observed data (sign + , (a)), refined monoclinic space group of $\mathrm{P} 2_{1} / \mathrm{M}$ model (full line, (b)), it's position of 2 theta (c), and the difference between the observed and the refined full line model $(\mathrm{d})$

SEM images with various magnification depicted in Fig.5 (a-c). Meanwhile, the related energy dispersive X-ray (EDX) analysis result on the selected surface as shown in Fig. 5(d) strongly indicates the presence of all elements contained in the complex except the hydrogen atom. It should be noted that the percentage ratio of the number of atoms does not represent the empirical formula of the complex, since it is not possible to have homogenous powder as indicated by the SEM images and it's EDX (Fig. 5). 


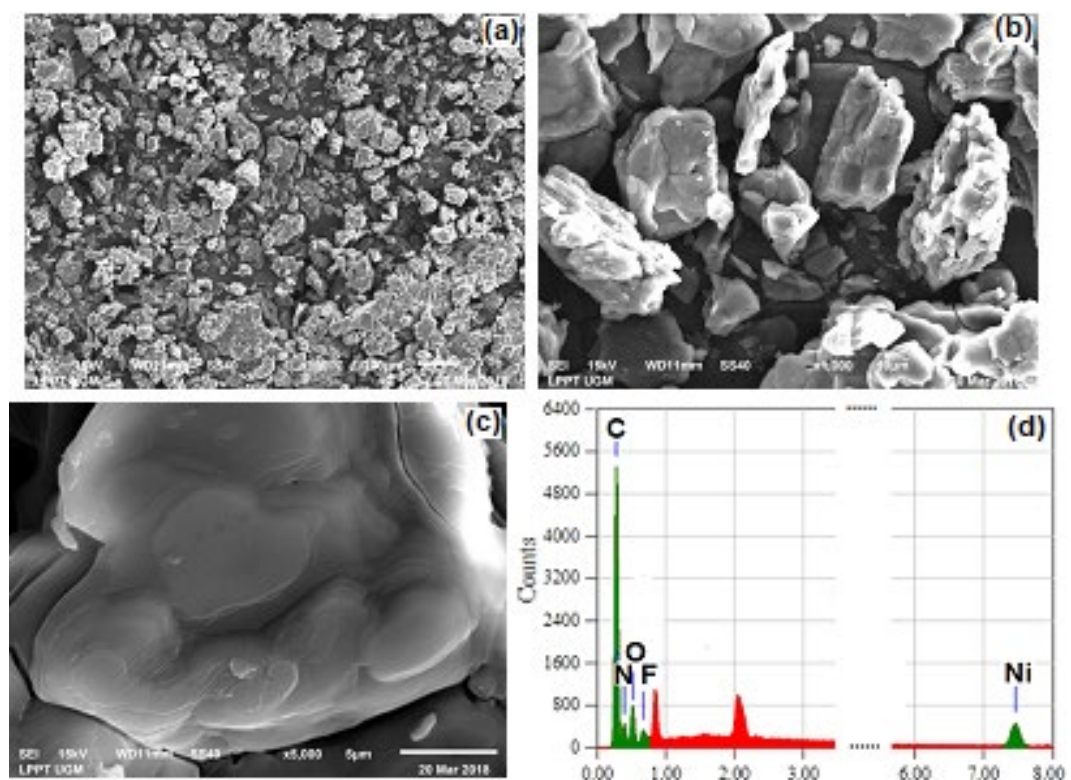

Fig 5. SEM images of $\left[\mathrm{Ni}(\text { bipy })_{3}\right]\left(\mathrm{CF}_{3} \mathrm{COO}\right)_{2} \cdot 6 \mathrm{H}_{2} \mathrm{O}$ at magnification of $100 \times(\mathrm{a}), 1000 \times(\mathrm{b}), 5000 \times(\mathrm{c})$ and its EDX analysis result showing the content of elements, Ni-C-F-N-O (d)

\section{- CONCLUSION}

The complex containing Ni-bipy-TFA has been successfully synthesized and its chemical properties have been characterized. The proposed empirical formula of the ionic complex, $\left[\mathrm{Ni}(\text { bipy })_{3}\right]\left(\mathrm{CF}_{3} \mathrm{COO}\right)_{2} \cdot 6 \mathrm{H}_{2} \mathrm{O}$, was estimated by the measurements of electrical equivalent conductance, and metal content (AAS), while the existence of hydrated water molecules, TFA ions, bipyridine molecules, and metal residue were signified by the corresponding TGA-DTA. The presence of elements was confirmed by EDX analysis. The magnetic moment was found to be normal paramagnet corresponding to two unpaired electrons with significant spin-orbit coupling. The UV-VIS spectral property of the complex exhibits the typical two main ligand field bands at the visible areas, and the third ligand field band as well as the charge transfer was observed at much high energy of UV area. The infrared spectrum of the complex shows the typical mode of vibrations of functional groups for bipyridine and the TFA anion. The powder X-Ray diffractogram refined using Le Bail method of Rietica program suggests the complex to adopt monoclinic symmetry of space group, $\mathrm{P} 2{ }_{1} / \mathrm{m}$.

\section{- REFERENCES}

[1] Palmer, R.A., and Piper, T.S., 1966, 2,2'-Bipyridine complexes. I. Polarized crystal spectra of tris(2,2'bipyridine)copper(II), -nickel(II), -cobalt(II), -iron(II), and -ruthenium(II), Inorg. Chem., 5 (5), 864-878.

[2] Prijamboedi, Z.B., Nugroho, A.A., and Ismunandar, 2009, Synthesis and structure analysis of aurivillius phases $\mathrm{Pb}_{1-\mathrm{x}} \mathrm{Bi}_{4+\mathrm{x}} \mathrm{Ti}_{4-\mathrm{x}} \mathrm{Mn}_{\mathrm{x}} \mathrm{O}_{15}$, J. Chin. Chem. Soc., 56 (6), 1108-1111.

[3] Wallwork, K.S., Pring A., Taylor M.R., and Hunter, B.A., 2003, A model for the structure of the hydrated aluminum phosphate, kingite determined by ab initio powder diffraction methods, Am. Mineral., 88 (1), 235-239.

[4] Wallwork, K.S., James, M., and Carter, M.L., 2006, The crystal chemistry, structure and properties of a synthetic carnotite-type compound, $\left.\mathrm{Ba}_{2}\left[\mathrm{UO}_{2}\right)_{2} \mathrm{Ti}_{2} \mathrm{O}_{8}\right]$, Can. Mineral., 44 (2), 433-442.

[5] Zhu, J.H., Wu, H.X., and Le Bail, A., 1999, Structure of $\left[\mathrm{Co}\left(\mathrm{NH}_{3}\right)_{5} \mathrm{CO}_{3}\right] \mathrm{NO}_{3} \cdot \mathrm{H}_{2} \mathrm{O}$, Solid State Sci., 1 (1), 55-62.

[6] Sugiyarto, K.H., Saputra, H.W., Permanasari, L., 
and Kusumawardani, C., 2017, Structural analysis of powder complex of $\left[\mathrm{Mn}(\text { phen })_{3}\right]\left(\mathrm{CF}_{3} \mathrm{SO}_{3}\right)_{2} \cdot 6.5 \mathrm{H}_{2} \mathrm{O}$, AIP Conf. Proc., 1847 (1), 040006.

[7] Kusumawardani, C., Permanasari, L., Fatonah S.D., and Sugiyarto, K.H., 2017, Structural analysis of powder complex of tris(1,10-phenanthroline) copper(II) trifluoromethane sulfonate dihydrate, Orient. J. Chem., 33 (6), 2841-2847.

[8] Kusumawardani, C., Kainastiti, F., and Sugiyarto, K.H., 2018, Structural analysis of powder complex of $\mathrm{Cu}(\text { bipy })_{3}\left(\mathrm{CF}_{3} \mathrm{SO}_{3}\right)_{2}\left(\mathrm{H}_{2} \mathrm{O}\right)_{\mathrm{x}}(\mathrm{x}=0.5,1)$, Chiang Mai J. Sci., 45 (4),1944-1952.

[9] Sutrisno, H., Kusumawardani, C., Rananggana, R.Y., and Sugiyarto, K.H., 2018, Structural analysis of powder tris(phenanthroline)nickel(II) trifluoro acetate, Chiang Mai J. Sci., 45 (7), 2768-2778.

[10] Anonymous, Trifluoroacetic acid, http://www.common organicchemistry.com/Common_Reagents/Trifluor oacetic_Acid/Trifluoroacetic_Acid.htm, accessed on April 2019.

[11] Table of Acids with Ka and pKa Values, 2013, Compiled from Appendix 5 Chem 1A, B, C Lab Manual and Zumdahl $6^{\text {th }}$ Ed., The pKa values for organic acids can be found in Appendix II of Bruice $5^{\text {th }}$ Ed., https://www.chem.purdue.edu/docs/exams/ 2013/April_20_2013_cume.pdf, accessed on April 2019.

[12] Tokareva, A.O., Tereshchenko, D.S., Boltalin, A.I., and Troyanov, S.I., 2006, Acid $\mathrm{Co}(\mathrm{II})$ and $\mathrm{Ni}(\mathrm{II})$ trifluoroacetate complexes: Synthesis and crystal structure, Russ. J. Coord. Chem., 32 (9), 663-668.

[13] Reiß, G.J., and Meyer, M.K., 2010, Synthesis and structural characterization of diisopropylammonium trifluoroacetate and diisoproplyammonium penta fluoropropionate, Z. Naturforsch. B, 65 (4), 479-484.

[14] Agambar, C.A., and Orrell, K.G., 1969, Trifluoroacetate complexes of cobalt(II), nickel(II), and copper(II) with pyridine-type ligands. Part I. Metal(II) trifluoroacetates and copper(II) complexes, J. Chem. Soc. A, 0, 897-904.

[15] Angulo, I.M., Bouwman, E., Lok, S.M., Lutz, M., Mul, W.P., and Spek, A.L., 2001, The first low-spin nickel complex with two coordinated water molecules,
[Ni(o-MeO-dppp) $\left.\left(\mathrm{H}_{2} \mathrm{O}\right)_{2}\right]\left(\mathrm{PF}_{6}\right)_{2}$-synthesis and structural characterization, Eur. J. Inorg. Chem., 2001 (6), 1465-1473.

[16] Figgis, B.N., and Lewis, J., 1960, Modern Coordination Chemistry, Interscience, New York.

[17] Sugiyarto, K.H., Kusumawardani, C., Wigati, H., and Sutrisno, H., 2019, Structural study of the powder complex of $\mathrm{Cu}(\mathrm{II})-1,10$-phenanthrolinetrifluoroacetate, Orient. J. Chem., 35 (1), 325-331.

[18] Sugiyarto, K.H., Kusumawardani, C., Sutrisno, H., and Wibowo, M.W.A., 2018, Structural analysis of powdered manganese(II) of 1,10-phenanthroline (phen) as ligand and trifluoroacetate (TFA) as counter anion, Orient. J. Chem., 34 (2), 735-742.

[19] Chandra, S., and Sangeetika, X., 2004, EPR, magnetic and spectral studies of copper(II) and nickel(II) complexes of Schiff base macrocyclic ligand derived from thiosemicarbazide and glyoxal, Spectrochim. Acta, Part A, 60 (1-2), 147-153.

[20] Eloussifi, H., Farjas J., Roura P., Ricart S., Puig T., Obradors X., and Dammak M., 2013, Thermo analytical study of the decomposition of yttrium trifluoroacetate thin films, Thin Solid Films, 545, 200-204.

[21] Laishram, N.S., 2012, Synthesis, characterization and thermal studies of copper(II) complexes of 2,2'bipyridyl and 1,10-phenanthroline, J. Chem. Pharm. Res., 4 (9), 4400-4405.

[22] Singh, V.P., Singh, P., and Singh, A.K., 2011, Synthesis, structural and corrosion inhibition studies on cobalt(II), nickel(II), copper(II) and zinc(II) complexes with 2-acetylthiophene benzoyl hydrazone, Inorg. Chim. Acta, 379 (1), 56-63.

[23] Ferenc, W., Walków-Dziewulska, A., Sarzynski, J., and Paszkowska, B., 2006, Magnetic, thermal and spectral properties of $\mathrm{Ni}$ (II) 2,3- , 3,5- and 2,6dimethoxybenzoates, Eclet. Quím., 31 (3), 53-60.

[24] Mabbs, F.E., and Machin, D.J., 1973, Magnetism and Transition Metal Complexes, Chapman and Hall, London.

[25] Abramov, V., 2010, New nickel(II) complexes with $\mathrm{N}$-donor ligands and anions as coligands. Structures and optical properties, Dissertation, 
Faculty of Mathematics and Natural Sciences, University of Cologne, Deutschland.

[26] Shad, H.A., Thebo, K.H., Ibupoto, Z.H., Malik, M.A., O’Brien, P., and Raftery, J., 2011, Synthesis, characterization, and crystal structure of a copper(II) complex of 1,10-phenanthroline and succinate, $J$. Coord. Chem., 64 (13), 2353-2360.

[27] Kumar, S.P., Suresh, R., Giribabu, K., Manigandan, R., Munusamy, S., Muthamizh, S., and Narayanan, V., 2014, Microwave synthesis of tris-(1,10phenanthroline) manganese(II) complex and its electrochemical sensing property of catechol, Int. J. ChemTech Res., 6 (6), 3280-3283.

[28] Chen, H., Xu, X.Y., Gao, J., Yang, X.J., Lu, L.D., and Wang, X., 2006, Study on crystal structure of $\left[\mathrm{Ni}(\text { phen })_{3}\right]\left(\mathrm{ClO}_{4}\right)_{2}$, Acta Phys. Chim. Sin., 22 (7), 856-859.

[29] Tosonian, S., Ruiz, C.J., Rios, A., Frias, E., and Eichler, J.F., 2013, Synthesis, characterization, and stability of iron (III) complex ions possessing phenanthroline-based ligands, Open J. Inorg. Chem., 3 (1), 7-13.

[30] Abdelhak, J., Cherni, S.N., and Zid, M.F., 2014, Synthesis, characterization, and crystal structure of new cobalt(III) complex: [Tris(1,10-phenanthroline$\left.\kappa^{2} N, N^{\prime}\right) \quad$ cobalt(III)] trinitrate monohydrate $\left[\mathrm{Co}\left(\mathrm{C}_{12} \mathrm{H}_{8} \mathrm{~N}_{2}\right)_{3}\right]\left(\mathrm{NO}_{3}\right)_{3} \cdot \mathrm{H}_{2} \mathrm{O}$, Mediterr. J. Chem., $3(1)$, 738-745.

[31] Zang, J., Wang, L.X., Zang, L., Chen, Y., and Zang, Q.T., 2013, Co-luminescence properties of terbium ions-benzoic acid-phen complexes doped with europium ions, Rare Met., 32 (6), 599-604.

[32] Skyrianou, K.C., Perdih, F., Turel, I., Kessissoglou, D.P., and Psomas, G., 2010, Nickel-quinolones interaction. Part 2 - Interaction of nickel(II) with the antibacterial drug oxolinic acid, J. Inorg. Biochem., 104 (2), 161-170.

[33] Suzuki, H., Takiguchi, T., and Kawasaki, Y., 1978, Synthesis and spectroscopy of acetato and dithiocarbamate complexes of bis(cyclopentadienyl) zirconium(IV), Bull. Chem. Soc. Jpn., 51 (6), 17641767.
[34] Osowole, A.A., Kolawole, G.A., and Fagade, O.E., 2008, Synthesis, characterization and biological studies on unsymmetrical Schiff-base complexes of nickel(II), copper(II) and zinc(II) and adducts with 2,2'-dipyridine and 1,10-phenanthroline, J. Coord. Chem., 61 (7), 1046-1055.

[35] Sinha, S.P., 1964, 2,2'-Dipyridyl complexes of rare earths. I: Preparation, infrared and some other spectroscopic data, Spectrochim. Acta, 20, 879-886.

[36] Lawrance, G.A., 1986, Coordinated trifluoro methanesulfonate and fluorosulfate, Chem. Rev., 86 (1), 17-33.

[37] Crowder, G.A., and Jackson, D., 1971, Infrared and Raman spectra of methyl trifluoroacetate, Spectrochim. Acta, Part A, 27 (9), 1873-1877.

[38] Crowder, G.A., 1971, Infrared spectra of trifluoro acetate esters, J. Fluorine Chem., 1 (2), 219-225.

[39] Fan, L., Wei, P., Pang, S., and Zhang, X., 2010, Tris(2,2'-bipyridine)nickel(II) hexamolybdate, Acta Crystallogr., Sect. E: Struct. Rep. Online, 66 (9), m1119.

[40] Zhou, Y., Li, X., Xu, Y., Cao, R., and Hong, M., 2003, Tris(2,2'-bipyridine)nickel(II) diperchlorate, Acta Crystallogr., Sect. E: Struct. Rep. Online, 59 (5), m300-m302.

[41] Golovnev, N.N., Molokeev, M.S., Sterkhova, I.V., Lesnikov, M.K., and Samoilo, A.S., 2019, Structure of bis(2-thiobarbiturate)Tris (2,2-bipyridyl)nickel(II) hexahydrate, J. Struct. Chem., 60 (1), 111-116.

[42] Ruiz-Perez, C., Lorenzo Luis, P.A., Lloret, F., and Julve, M., 2002, Dimensionally controlled hydrogenbonded nanostructures: Synthesis, structure, thermal, and magnetic behaviour of the tris(chelated) nickel(II) complex $\left[\mathrm{Ni}(\text { bipy })_{3}\right] \mathrm{Cl}_{2} \cdot 5 \cdot 5 \mathrm{H}_{2} \mathrm{O}$ (bipy $=$ 2,2'-bipyridyl), Inorg. Chim. Acta, 336, 131-136.

[43] Lin, S.H., Wang, Z.K., Zhang, B.H., Hu, H.M., and Huang, J.S., 2000, Crystal structure of tris(2,2'bipyridine)nickel(II) tetrachlorozincate, Chin. J. Chem., 19 (2), 95-98.

[44] Toby, B.H., 2006, R factors in Rietveld analysis: How good is good enough?, Powder Diffr., 21 (1), $67-70$. 